\title{
Toxicological Evaluation of Anti-Scrapie Trimethoxychalcones and Oxadiazoles
}

\author{
CLAUDIA P. FIGUEIREDO ${ }^{1}$, NATALIA C. FERREIRA ${ }^{1}$, GISELLE F. PASSOS ${ }^{1}$, ROBSON DA COSTA $^{1}$, FERNANDA \\ S. NEVES ${ }^{1}$, CLARICE S.C. MACHADO ${ }^{1}$, ALESSANDRA MASCARELLO $^{2}$, LOUISE D. \\ CHIARADIA-DELATORRE ${ }^{2}$, PATRÍCIA D. NEUENFELDT ${ }^{2}$, RICARDO J. NUNES ${ }^{2}$ and YRAIMA CORDEIRO ${ }^{1}$
}

\author{
${ }^{1}$ Faculdade de Farmácia, Universidade Federal do Rio de Janeiro, \\ Av. Carlos Chagas Filho, 373, 21941-902 Rio de Janeiro, RJ, Brasil \\ ${ }^{2}$ Departamento de Química, Universidade Federal de Santa Catarina, \\ Campus Universitário Trindade, 88040-900 Florianópolis, SC, Brasil
}

Manuscript received on December 23, 2014; accepted on publication April 9, 2015

\begin{abstract}
An altered form of the cellular prion protein, the $\operatorname{PrP}^{\mathrm{Sc}}$ or $\operatorname{PrP}^{\mathrm{Res}}$, is implicated in the occurrence of the still untreatable transmissible spongiform encephalopathies. We have previously synthesized and characterized aromatic compounds that inhibit protease-resistant prion protein $\left(\mathrm{PrP}^{\mathrm{Res}}\right)$ accumulation in scrapie-infected cells. These compounds belong to different chemical classes, including acylhydrazones, chalcones and oxadiazoles. Some of the active compounds were non-toxic to neuroblastoma cells in culture and seem to possess drugable properties, since they are in agreement with the Lipinski's rule of 5 and present desirable pharmacokinetic profiles as predicted in silico. Before the evaluation of the in vivo efficacy of the aromatic compounds in scrapie-infected mice, safety assessment in healthy mice is needed. Here we used Swiss mice to evaluate the acute toxicity profile of the six most promising anti-prionic compounds, the 2,4,5-trimethoxychalcones (J1, J8, J20 and J35) and the 1,3,4-oxadiazoles (Y13 and Y17). One single oral administration $(300 \mathrm{mg} / \mathrm{kg}$ ) of J1, J8, J20, J35, Y13 and $\mathrm{Y} 17$ or repeated intraperitoneal administration $(10 \mathrm{mg} / \mathrm{kg}, 3$ times a week, for 4 weeks) of J1, J8 and J35, did not elicit toxicity in mice. We strongly believe that the investigated trimethoxychalcones and oxadiazoles are interesting compounds to be further analyzed in vivo against prion diseases.
\end{abstract}

Key words: prion, acute toxicity, organic compound, drug safety, scrapie, pharmacokinetics.

\section{INTRODUCTION}

Prion diseases or transmissible spongiform encephalopathies (TSEs) are severe neurodegenerative disorders that still lack efficient treatment. An abnormal form of the cellular prion protein $(\mathrm{PrP})$, the scrapie $\operatorname{PrP}\left(\operatorname{PrP}^{\mathrm{Sc}}\right)$, is involved in the establishment of TSEs (Prusiner 1998). $\mathrm{PrP}^{\mathrm{Sc}}$ is partially protease-

Correspondence to: Yraima Cordeiro

E-mail: yraima@pharma.ufrj.br resistant, poorly soluble in aqueous solvents and accumulates in its aggregated form in the brain of affected individuals. Most experimental approaches against TSEs focused either on inhibiting the conversion of $\operatorname{PrP}^{\mathrm{C}}$ to $\mathrm{PrP}^{\mathrm{Sc}}$ or on controlling the clearance of $\mathrm{PrP}^{\mathrm{Sc}}$ from infected cells and tissues (Kocisko et al. 2003, Kocisko and Caughey 2006, Rainov et al. 2007, Forloni et al. 2013, Cordeiro and Ferreira 2015). Several classes of aromatic or- 
ganic compounds have been screened for these effects, such as quinolines, acridines, oxadiazoles, chalcones, 2-aminothiazoles, arylamides, among others (Doh-ura et al 2000, Korth et al. 2001, Koster et al. 2003, Cashman and Caughey 2004, Ghaemmaghami et al. 2010, Macedo et al. 2010, Sim 2012, Li et al. 2013, Ferreira et al. 2014). The majority of tests have used cultured mammalian cells infected with the scrapie form of PrP obtained from different sources (murine, hamster) (Kocisko et al. 2003, Kocisko and Caughey 2006, Sim 2012, Ferreira et al. 2014). Their ability to reduce $\operatorname{PrP}^{\mathrm{Sc}}$ (or $\mathrm{PrP}^{\mathrm{Res}}$ ) levels in vitro is usually evaluated using anti-PrP antibodies in proteinase-K treated cells. Although several of these compounds show low $\mathrm{IC}_{50}$ values (nM range), only a few were able to cross the blood brain barrier (BBB) and/or were evaluated for their pharmacokinetic profile (Koster et al. 2003, Silber et al. 2013). Flupirtine, quinacrine, chlorpromazine, pentosan polysulfate (PPS) and doxycycline have even been tested in humans, and even though clinical improvement and marginally increase in the survival time (for PPS) were observed in some cases, none of them were able to reverse or even to halt the clinical course of the disease (Furukawa et al. 2002, Cashman and Caughey 2004, Otto et al. 2004, Martínez-Lage et al. 2005, Rainov et al. 2007, Tsuboi et al. 2009, Collinge et al. 2009, Forloni et al. 2013, Haïk et al. 2014). The investigation of drugs/phytotherapics already commercialized with other clinical indications has helped to overcome the toxicological limitations of studying new compounds and administering them to animal models and humans. However, newly developed molecules might possess better efficacy and safety compared to old ones and could represent an important step in the development of antiscrapie therapeutic strategies. Nevertheless, initial toxicological analysis and evaluation of the pharmacokinetic (PK) profile of these new substances are indeed needed.
We have recently identified a new panel of aromatic hetero and homocyclic compounds with anti-scrapie activity by screening in scrapie-infected neuroblastoma ( $\mathrm{ScN} 2 \mathrm{a}$ ) cells (Ferreira et al. 2014, Cordeiro and Ferreira 2015). Among 50 active compounds, we identified four trimethoxychalcones (named J1, J8, J20, J35) and two oxadiazoles (Y13 and Y17) with $\mathrm{IC}_{50} \sim 1 \mu \mathrm{M}$ (Js) and $\sim 10 \mu \mathrm{M}$ (Ys), respectively, obtained after incubation with $\mathrm{ScN} 2 \mathrm{a}$ cells for 4 days. In silico PK and physico-chemical predictions indicated that these compounds have promising drug characteristics, such as reduced mutagenicity, high permeation to the central nervous system and high oral bioavailability (Ferreira et al. 2014). One study has shown that the chalcones J8, J20 and J35 at $100 \mu \mathrm{M}$, reduced the viability of human K562 acute myeloid leukemia cells from 30-50 \% (Costa et al. 2014). J1 inhibited the activity of cruzain from $T$. cruzi with an $\mathrm{IC}_{50}$ of $100 \mu \mathrm{M}$ (Borchhardt et al. 2010). However, even for the compounds that had different biological/ pharmacological activities, they did not match the potential anti-scrapie activity, as the $\mathrm{IC}_{50}$ values obtained in ScN2a cells were significantly lower than those reported (Borchhardt et al. 2010, Costa et al. 2014). Therefore, we do not expect that the compounds are at a risk of presenting unwanted pharmacological side effects during their preclinical and clinical trials.

Here, we assessed the safety of compounds J1, J8, J20, J35, Y13 and Y17 (Fig. 1) by evaluating their toxic effects after acute oral administration or following repeated intraperitoneal administration in mice. The development of behavioural alterations (Hippocratic test), food and water intake, were evaluated. In addition, the effect of the compounds on lethality was investigated during the first $24 \mathrm{~h}$ and for 14 or 28 days in order to assess the possible alterations related to the course of treatment. Animals were sacrificed at the end of the observation period and assessment of macroscopic 

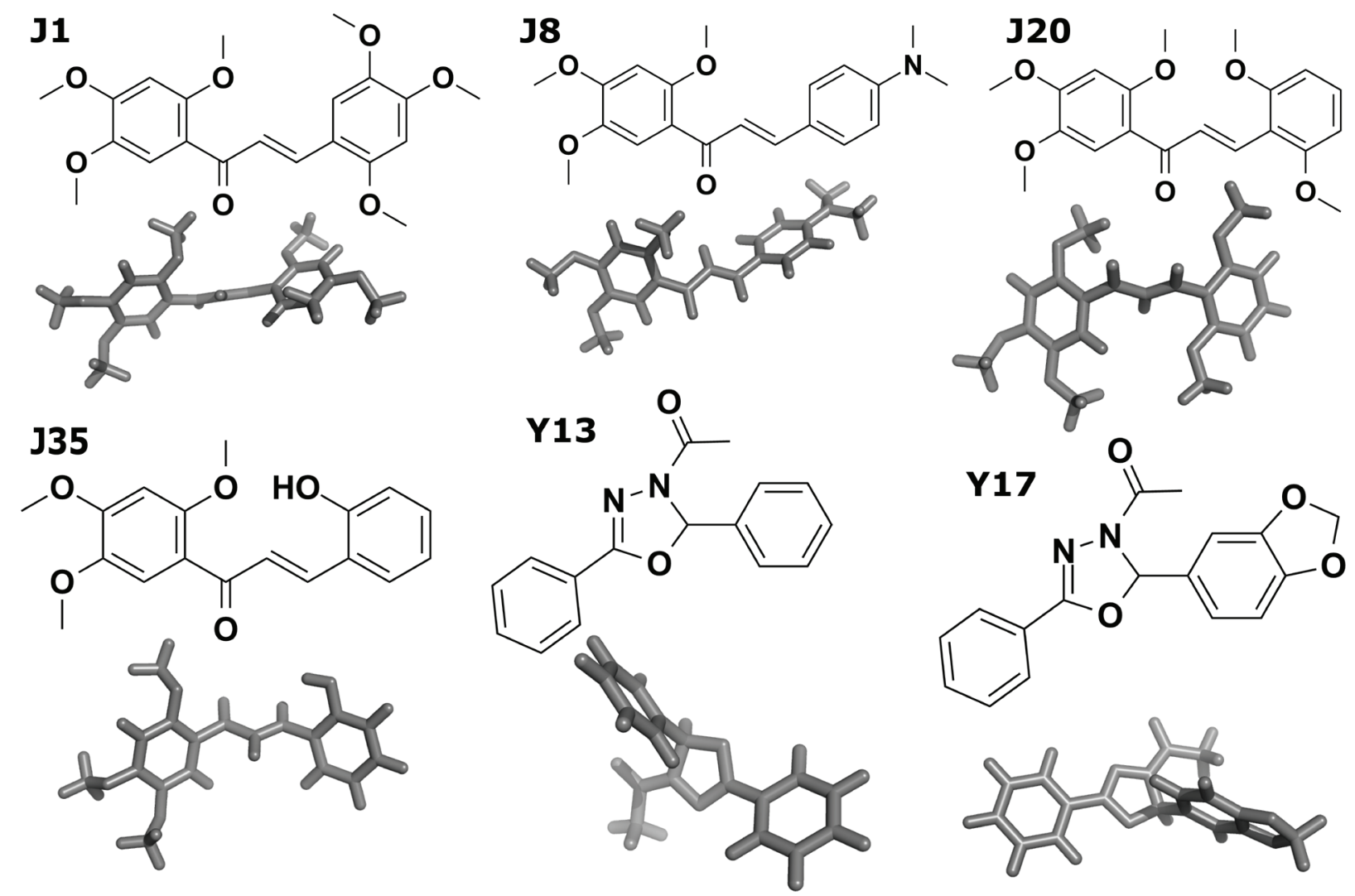

Figure 1 - Two-dimensional (2D) and three-dimensional (3D) structures of the compounds presenting anti-scrapie activity evaluated in this study. The 3D structures (shown below each respective 2D structure) were obtained with AVOGADRO software, as described (Ferreira et al. 2014). Stick representation was made with PyMOL (The PyMOL Molecular Graphics System, Version 1.3.r.1eduSchrödinger, LLC.).

alterations in several organs and/or glands was performed.

None of the investigated compounds caused death of the mice at the administered dose and no macroscopic alterations were seen in the selected organs or glands following oral administration. Our results indicate that $\mathrm{LD}_{50}$ is higher than 300 $\mathrm{mg} / \mathrm{kg}$ for all studied compounds, and that oral administration of 2,4,5-trimethoxychalcones and $1,3,4$-oxadiazoles is safe in doses of up to 300 $\mathrm{mg} / \mathrm{kg}$. In addition, they can also be considered safe for systemic administration, since only one mouse treated with J8 and one with J35 (both intraperitoneal administration) showed minor lung bleeding, kidney discoloration and increased relative weight of the heart, when compared with the control group. This toxicological evaluation provides preliminary information for in vivo studies in scrapie-infected murine models.

\section{MATERIALS AND METHODS}

\section{COMPOUNDS}

Compound J1 ( $12 E)-1-\left(2^{\prime}, 4^{\prime}, 5^{\prime}\right.$ trimethoxyphenyl)-3-(2,4,5 trimethoxyphenyl)2-propen-1-one), J8 (2E)-3-[4-(dimethylamino) phenyl]-1-(2,4,5-trimethoxyphenyl)prop-2-en-1one, J20 ((2E)-1-(2',4',5'-trimethoxyphenyl)-3(2,6-dimethoxyphenyl)-2-propen-1-one), J35 (2E)3-(2-hydroxyphenyl)-1-(2,4,5-trimethoxyphenyl) prop-2-en-1-one, Y13 1-[(2R)-2-(cyclohexa-1,5dien-1-yl)-5-phenyl-1,3,4-oxadiazol-3(2H)-yl] 
ethanone, and Y17 (1-[(2R)-2-(1,3-benzodioxol-5yl)-5-phenyl-1,3,4-oxadiazol-3(2H)-yl]ethanone) were synthesized and characterized as previously described (Borchhardt et al. 2010, Nunes et al. 2012, Costa et al. 2014).

\section{ANIMALS}

Acute oral toxicity experiments were conducted on 36 male and 38 female adult Swiss mice (6-8 weeks old, 22-27 g), and repeated intraperitoneal doses were conducted on 24 female adult Swiss mice (8-12 weeks old, 30-35 g). The animals were purchased from Central Biotery of Fundação Oswaldo Cruz (FIOCRUZ - Rio de Janeiro/ $\mathrm{RJ})$. Animals were housed in the vivarium at the School of Pharmacy, CCS, UFRJ. Animals were housed in clear microisolator cages $(40 \times 32 \times 17 \mathrm{~cm})$ (ALESCO, Campinas, Brazil), with controlled temperature $\left(22 \pm 2{ }^{\circ} \mathrm{C}\right)$, humidity between $60-80$ $\%$ on a 12 -h light/dark cycle, with food and water ad libitum. All experiments were conducted in accordance with the ethical principles set forth by the Brazilian School of Animal Experimentation (COBEA 1991) and with the approval of the Ethics Committee for Animal Experimentation (CEUA) of the Federal University of Rio de Janeiro (Protocol FARMACIA07-04/16). Prior to experimentation, animals were individually identified in order to evaluate behaviour and body weight during the period of study, as well as to evaluate organ weight at the end of the experiments.

\section{In silico PREDICTION OF TOXICOLOGICAL PROPERTIES}

Physicochemical and toxicity properties of compounds J1, J8, J20, J35, Y13 and Y17 were predicted with software modules from ACD/ Labs Percepta Platform, version 12.01, Advanced Chemistry Development, Inc., Toronto, On, Canada (www.acdlabs.com 2014) (ttp://www. acdlabs.com/products/percepta/predictors.php) from the uploaded three-dimensional structure of the compounds. Software components provided by ACD/Labs (from PhysChem Modules and Toxicity
Modules) were used to predict aqueous solubility, toxicity category and $\mathrm{LD}_{50}$ values for the selected compounds. We used the $\mathrm{LD}_{50}$ module that predicts $\mathrm{LD}_{50}$ values $(\mathrm{mg} / \mathrm{kg})$ for rats and mice according to various routes of administration, and the Toxicity Categories module that classifies compounds into OECD categories for acute oral toxicity. OECD assigns chemicals to one of the five Oral Acute Toxicity Hazard Categories according to the $\mathrm{LD}_{50}$ values after oral administration to mice, which are: $\mathrm{V}$, 2000 to $5000 \mathrm{mg} / \mathrm{kg}$ (may be harmful if swallowed); IV, 300 to $2000 \mathrm{mg} / \mathrm{kg}$ (harmful if swallowed); III, 50 to $300 \mathrm{mg} / \mathrm{kg}$ (toxic if swallowed); II, 5 to 50 $\mathrm{mg} / \mathrm{kg}$ (fatal if swallowed); $\mathrm{I},<5 \mathrm{mg} / \mathrm{kg}$ (fatal if swallowed). Predictions are provided as a list of probabilities that the compound's $\mathrm{LD}_{50}$ (rat, oral route) would exceed the cut-off values separating different categories. On the basis of these values, the software selects the most probable OECD Hazard categories for that compound. For both solubility and $\mathrm{LD}_{50}$ calculation a reliability index (RI) value is provided that represents a quantitative evaluation of prediction confidence. In general, RI values below 0.3 indicate that the respective prediction is not reliable.

PREPARATION OF THE J1, J8, J20, J35,

Y13 AND Y17 COMPOUNDS

Stocks solutions were prepared according to the proposed doses (based on in silico $\mathrm{LD}_{50}$ prediction) and considering the estimated water solubility of the compounds. Stock solutions of compounds were prepared by solubilising the compound in $0.9 \%$ $\mathrm{NaCl}$ supplemented with Tween 80 at $8 \%$ (for i.p. administration) or $10 \%$ (for oral administration).

ORAL ACUTE TOXICITY

In order to investigate the possible acute toxicity of the trimethoxychalcones (J1, J8, J20, J35) and oxadiazoles (Y13 and Y17), groups of 10 to 12 mice (male and female) were starved for $4 \mathrm{~h}$ and J1, J8, J20, J35, Y13 or Y17 (300 mg/kg) or vehicle was administered orally. Control groups received 
vehicle (0.9\% $\mathrm{NaCl}$ containing $10 \%$ Tween 80, 10 $\mathrm{mL} / \mathrm{kg}$, p.o.). After oral administration of vehicle or the compounds, animals were arranged in groups and kept in clear microisolator cages for 14 days. Parameters indicative of toxicity, such as abdominal constriction, ptosis, piloerection, tremors, paralysis, tremor, reduction of body tonus, convulsions (seizures), corneal reflex, touch response, tail grip, and mortality were evaluated $0.25,0.5,1,2,4,8$ and $24 \mathrm{~h}$ after treatment (Brandão 2004, OECD 2001). The dose selection was based on OECD/ OCDE Guideline 423, which suggests that when there is no information on a substance to be tested, for animal welfare reasons, it is recommended to use the starting dose of $300 \mathrm{mg} / \mathrm{kg}$ body weight (OECD 2001).

The possible influence of acute administration of compounds on food and water intake, weight gain, as well as on some vital organs was assessed. Thus, animals were kept in microisolator cages and on the $1^{\text {st }}, 4^{\text {th }}, 7^{\text {th }}, 9^{\text {th }}, 11^{\text {th }}$ and $14^{\text {th }}$ day after administration of J1, J8, J20, J35, Y13 and Y17 (300 mg/kg) or vehicle, body weight, food and water intake were evaluated. On the $14^{\text {th }}$ day of observation, animals were anesthetized and sacrificed by cervical displacement and subjected to laparotomy, which allowed macroscopic observation (general aspect, colour and weight) of organs and/or glands, such as: heart, lung, liver, kidney, spleen, stomach, testis, ovary and uterine tubes, salivary gland, adrenal gland, thymus, mesenteric lymph node and encephalon.

\section{SYSTEMIC TOXICITY}

To analyze the possible systemic toxicity of the trimethoxychalcones, mice were grouped in microisolator cages $(n=6)$, and received J1, J8 or J35 (10 mg/kg), administered via intraperitoneal (i.p.) route three times a week for four weeks. The control group received vehicle $(0.9 \% \mathrm{NaCl}$ containing $8 \%$ Tween $80,10 \mathrm{~mL} / \mathrm{kg}$, i.p.) at the same intervals. Parameters indicative of toxicity, as well as body weight and relative weight of some organs were assessed as described for the oral acute toxicity experiments. Mice were evaluated every other day and sacrificed after 28 days. Macroscopic observation of organs was performed as described for the oral acute toxicity experiments.

\section{STATISTICAL ANALYSES}

Results are expressed as mean \pm standard error mean or as mean with $95 \%$ of confidence interval. Statistical analysis of results was performed using one- or two-way analysis of variance (ANOVA) followed by post-hoc Newman-Keuls test when appropriate. For absolute body weight comparison, two-way ANOVA with repeated measures was performed. Differences from the control group were considered to be significant when $\mathrm{P}<0.05$.

\section{RESULTS}

One of the limitations to explore new compounds as possible drug candidates is the lack of pharmacokinetic and toxicological information, which limits their application in clinical studies. We have previously described novel chalcones and oxadiazoles with potent anti-scrapie activity, as seen by the clearance of protease-resistant PrP $\left(\mathrm{PrP}^{\mathrm{Res}}\right.$ ) from prion scrapie infected cells (Ferreira et al. 2014). Here we describe a preliminary acute toxicity evaluation of the compounds that had low $\mathrm{IC}_{50}$ values and suitable $\mathrm{PK}$ properties predicted in silico.

Prior to proceeding with the toxicological analysis, acute toxicity and aqueous solubility were predicted in silico for the compounds that: were active in the dot-blot assay (clearance of $\operatorname{PrP}^{\text {Res }}$ from $\mathrm{ScN} 2 \mathrm{a}$ cells), were non-toxic to N2a cells, had good PK characteristics and were predicted to directly interact with $\operatorname{PrP}^{\mathrm{C}}$ (Ferreira et al. 2014). The software modules from ACD/Labs Percepta Platform were used. All compounds were predicted to have low solubility in water, as expected from their chemical structure. The obtained results are summarized in Table I. Prediction of aqueous solubility for the oxadiazoles Y13 and Y7 was not 
reliable because RI values were very low ( 0.13 and 0.32 ), probably due to the lack of experimental values for compounds with similar structures. However, they were partially solubilized in Tween 80 from 8 to $10 \%$. We used two software components related to acute toxicity provided by ACD/Labs Acute Toxicity predictor. Compounds from the $\mathrm{J}$ series (2,4,5-trimethoxychalcones) were predicted as being less toxic than compounds from the $\mathrm{Y}$ series (1,3,4-oxadiazoles), according to the classification into OECD toxicity categories and the calculated $\mathrm{LD}_{50}$ values (Table I).

The compounds had anti-scrapie activity in the dot-blot assay at $\mathrm{IC}_{50}$ values ranging from 1 to 10 $\mu \mathrm{M}$ (from $\sim 0.4$ to $4.0 \mathrm{mg} / \mathrm{L}$ ) (Ferreira et al. 2014); these values, along with the predicted $\mathrm{LD}_{50}$ and solubility values reported here, guided us to select the best dosing regimen for the toxicology studies. Our toxicity studies were performed in accordance with the specifications of the Agência Nacional de Vigilância Sanitária/Brazilian Sanitary Agency (ANVISA) and The Organisation for Economic Co-operation and Development (OECD). For acute toxicity tests, ANVISA recommends the use of a dose which corresponds to at least tenfold the clinical exposure dose (ANVISA 2010). Since our compounds were effective from 1 to $10 \mu \mathrm{M}$, the maximum dose would be $4.0 \mathrm{mg} / \mathrm{kg}$ and the acute toxicity test should be performed using a dose of at least $40 \mathrm{mg} / \mathrm{kg}$. However, to work with a wide safety margin and based on OECD Guideline 423 (OECD 2001) we used a single dose of $300 \mathrm{mg} /$ $\mathrm{kg}$. Regarding the multiple dose toxicity study, ANVISA recommends a dose lower than $1,000 \mathrm{mg} /$ $\mathrm{kg} /$ day.

For 14 days we investigated the acute toxicity of J1, J8, J20, J35, Y13, and Y17 (diluted in $10 \%$ Tween 80 ), administered orally at a single dose of

TABLE I

Prediction of aqueous solubility and acute toxicity of compounds.

\begin{tabular}{|c|c|c|c|c|c|}
\hline Compound & $\begin{array}{c}\text { Probable solubility in } \\
\text { water }^{\mathrm{a}} \\
(\mathrm{mg} / \mathrm{mL})\end{array}$ & $\begin{array}{c}\text { Toxicity } \\
\text { Category }^{b}\end{array}$ & $\begin{array}{c}\mathrm{LD}_{50}=<5000(\mathrm{Js}) \\
\text { or }<2000 \mathrm{mg} / \mathrm{kg} \\
(\text { Ys) }\end{array}$ & $\begin{array}{c}\mathrm{LD}_{50}>\mathbf{3 0 0}(\mathrm{Js}) \\
\text { or }>50 \mathrm{mg} / \mathrm{kg}(\mathrm{Ys})\end{array}$ & $\begin{array}{l}\text { Prediction of } \mathrm{LD}_{50} \\
\text { values }(\mathrm{mg} / \mathrm{kg})^{\mathrm{c}^{5}}\end{array}$ \\
\hline J1 & $\begin{array}{c}>0.01(\text { RI 0.68) } \\
P=0.93\end{array}$ & 4 or 5 & $82 \%$ & $94 \%$ & $\begin{array}{l}\text { i.p.: } 830 \\
\text { oral: } 1300\end{array}$ \\
\hline J8 & $\begin{array}{c}>0.010(\mathrm{RI} 0.57) \\
\mathrm{P}=0.8\end{array}$ & 4 or 5 & $82 \%$ & $95 \%$ & $\begin{array}{l}\text { i.p.: } 650 \\
\text { oral: } 1100\end{array}$ \\
\hline $\mathbf{J} 20$ & $\begin{array}{c}>0.01(\mathrm{RI} 0.56) \\
\mathrm{P}=0.8\end{array}$ & 4 or 5 & $79 \%$ & $95 \%$ & $\begin{array}{l}\text { i.p.: } 680 \\
\text { oral: } 1100\end{array}$ \\
\hline J35 & $\begin{array}{c}>0.01(\mathrm{RI} 0.59) \\
\mathrm{P}=0.97\end{array}$ & 4 or 5 & $78 \%$ & $96 \%$ & $\begin{array}{l}\text { i.p.: } 580 \\
\text { oral: } 1300\end{array}$ \\
\hline Y13 & $\begin{array}{c}>0.01(\mathrm{RI} 0.13) \\
\mathrm{P}=0.85\end{array}$ & 3 or 4 & $85 \%$ & $93 \%$ & $\begin{array}{l}\text { i.p.: } 960 \\
\text { oral: } 560\end{array}$ \\
\hline Y17 & $\begin{array}{c}>0.01(\text { RI 0.32) } \\
P=0.97\end{array}$ & 3 or 4 & $8 \%$ & $92 \%$ & $\begin{array}{l}\text { i.p.: } 640 \\
\text { oral: } 310\end{array}$ \\
\hline
\end{tabular}

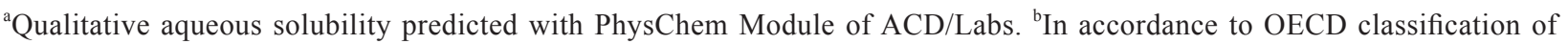
compounds into one of five OECD categories for acute oral toxicity (Acute Toxicity Prediction Module). ${ }^{\mathrm{c} P r e d i c t i o n}$ of $\mathrm{LD}_{50} \mathrm{values}$ for mice according to various routes of administration (Acute Toxicity Prediction Module); RI values for J compounds were $>0.4$ and for $\mathrm{Y}>0.3$. 
$300 \mathrm{mg} / \mathrm{kg}$ to 74 Swiss mice (36 male and 38 female, 10 to 12 animals per group). Acute treatment with all compounds (at $300 \mathrm{mg} / \mathrm{kg}$ ) or vehicle, administered orally, caused $10 \%$ of lethality in mice, which was not significantly different from the control group (Table II). In addition, acute treatment with the compounds or vehicle did not induce behavioral alterations indicative of acute toxicity in either male or female mice, such as piloerection, tremors, reduction of body tonus, abdominal constrictions, convulsions (seizures), touch response, tail grip or corneal reflex, when compared with the control group (vehicle) (Table III, IV and V).

Food and water intake were not modified significantly upon acute oral treatment with the compounds or vehicle compared with the control group (Table VI). Corroborating these findings, the treatment with J1, J8, J20, J35, Y13 and Y17 (300 mg/kg) or vehicle, administered orally

TABLE II

Effect of acute treatment with J1, J8, J20, J35, Y13 and Y17 (300 $\mathrm{mg} / \mathrm{kg})$ or vehicle, administered orally, on the mice mortality percentage.

\begin{tabular}{|c|c|c|c|}
\hline $\begin{array}{c}\text { Compound } \\
\text { p.o. } \\
(300 \mathrm{mg} / \mathrm{kg})\end{array}$ & Sex & $\mathbf{n}$ & $\begin{array}{l}\text { Mortality } \\
(\%)\end{array}$ \\
\hline \multirow{2}{*}{ Vehicle } & Male & 5 & \multirow{2}{*}{10} \\
\hline & Female & 5 & \\
\hline \multirow{2}{*}{ J1 } & Male & 7 & \multirow{2}{*}{0} \\
\hline & Female & 5 & \\
\hline \multirow{2}{*}{ J8 } & Male & 4 & \multirow{2}{*}{0} \\
\hline & Female & 7 & \\
\hline \multirow{2}{*}{$\mathrm{J} 20$} & Male & 4 & \multirow{2}{*}{0} \\
\hline & Female & 6 & \\
\hline \multirow{2}{*}{ J35 } & Male & 7 & \multirow{2}{*}{10} \\
\hline & Female & 3 & \\
\hline \multirow{2}{*}{ Y13 } & Male & 4 & \multirow{2}{*}{0} \\
\hline & Female & 7 & \\
\hline \multirow{2}{*}{ Y17 } & Male & 5 & \multirow{2}{*}{0} \\
\hline & Female & 5 & \\
\hline
\end{tabular}

$\mathrm{n}$ : number of animals. to mice, did not significantly change absolute body weight of animals when compared with the control group (Fig. 2). Three animals treated with Y17 had diarrhea in the first hour following administration. In addition, mice which received acute treatment with the compounds at $300 \mathrm{mg} /$ $\mathrm{kg}$, administered orally, showed no important macroscopic alterations considering aspect and color of the selected organs and glands (heart, lung, liver, kidney, spleen, stomach, testis, ovary and uterine tubes, salivary gland, adrenal gland,

\section{TABLE III}

Effect of acute treatment with J1, J8, J20, J35, Y13 and Y17 $(300 \mathrm{mg} / \mathrm{kg})$ or vehicle, observed during $0.25,0.5,1,2,4$, 8 and $24 \mathrm{~h}$ after oral administration, on some behavioural parameters indicative of acute toxicity in mice.

\begin{tabular}{|c|c|c|}
\hline $\begin{array}{c}\text { Evaluated } \\
\text { parameters }\end{array}$ & $\begin{array}{c}\text { Dose } \\
(300 \mathrm{mg} / \mathrm{kg}, \\
\text { p.o. })\end{array}$ & Response \\
\hline \multirow{7}{*}{$\begin{array}{l}\text { Touch } \\
\text { response }\end{array}$} & Vehicle & Not observed \\
\hline & $\mathrm{J} 1$ & $\begin{array}{c}\text { Present in } 1 / 12 \text { animals, } \\
2 \mathrm{~h} \text { after treatment }\end{array}$ \\
\hline & $\mathrm{J} 8$ & Not observed \\
\hline & $\mathrm{J} 20$ & Not observed \\
\hline & $\mathrm{J} 35$ & Not observed \\
\hline & Y13 & Not observed \\
\hline & Y17 & Not observed \\
\hline \multirow{7}{*}{ Tail grip } & Vehicle & Not observed \\
\hline & $\mathrm{J} 1$ & Not observed \\
\hline & $\mathrm{J} 8$ & Not observed \\
\hline & $\mathrm{J} 20$ & Not observed \\
\hline & $\mathrm{J} 35$ & Not observed \\
\hline & Y13 & Not observed \\
\hline & Y17 & Not observed \\
\hline \multirow{6}{*}{$\begin{array}{l}\text { Corneal } \\
\text { reflex }\end{array}$} & Vehicle & Not observed \\
\hline & $\mathrm{J} 1$ & Not observed \\
\hline & $\mathrm{J} 8$ & Not observed \\
\hline & $\mathrm{J} 20$ & Not observed \\
\hline & $\mathrm{J} 35$ & Not observed \\
\hline & Y13 & Not observed \\
\hline
\end{tabular}

Values are expressed as the number of animals which presented behavioural alterations in comparison with the total number of evaluated animals. 


\section{TABLE IV}

Effect of acute treatment with $\mathbf{J 1}, \mathbf{J 8}, \mathbf{J 2 0}, \mathbf{J 3 5}, \mathrm{Y} 13$ and

Y17 (300 mg/kg) or vehicle, observed during $0.25,0.5$,

$1,2,4,8$ and $24 \mathrm{~h}$ after oral administration, on some behavioural parameters indicative of acute toxicity in mice.

\begin{tabular}{|c|c|c|}
\hline $\begin{array}{l}\text { Evaluated } \\
\text { parameters }\end{array}$ & $\begin{array}{c}\text { Dose } \\
(300 \mathrm{mg} / \mathrm{kg}, \\
\text { p.o. })\end{array}$ & Response \\
\hline \multirow{7}{*}{$\begin{array}{l}\text { Abdominal } \\
\text { constrictions }\end{array}$} & Vehicle & Not observed \\
\hline & $\mathrm{J} 1$ & Not observed \\
\hline & $\mathrm{J} 8$ & $\begin{array}{c}\text { Present in } 1 / 11 \text { animals, } \\
0.25 \mathrm{~h} \text { after treatment }\end{array}$ \\
\hline & $\mathrm{J} 20$ & Not observed \\
\hline & $\mathrm{J} 35$ & Not observed \\
\hline & Y13 & Not observed \\
\hline & Y17 & Not observed \\
\hline \multirow{7}{*}{ Body tonus } & Vehicle & Not observed \\
\hline & $\mathrm{J} 1$ & Not observed \\
\hline & $\mathrm{J} 8$ & Not observed \\
\hline & $\mathrm{J} 20$ & Not observed \\
\hline & $\mathrm{J} 35$ & Not observed \\
\hline & Y13 & Not observed \\
\hline & Y17 & Not observed \\
\hline \multirow{7}{*}{ Tremors } & Vehicle & $\begin{array}{c}\text { Present in } 1 / 10 \text { animals, } \\
0.5 \mathrm{~h} \text { after treatment }\end{array}$ \\
\hline & $\mathrm{J} 1$ & Not observed \\
\hline & $\mathrm{J} 8$ & Not observed \\
\hline & $\mathrm{J} 20$ & Not observed \\
\hline & $\mathrm{J} 35$ & Not observed \\
\hline & Y13 & Not observed \\
\hline & Y17 & Not observed \\
\hline \multirow{7}{*}{$\begin{array}{l}\text { Convulsions/ } \\
\text { Seizures }\end{array}$} & Vehicle & $\begin{array}{c}\text { Present in } 1 / 10 \text { animals, } \\
0.5 \mathrm{~h} \text { after treatment }\end{array}$ \\
\hline & $\mathrm{J} 1$ & Not observed \\
\hline & $\mathrm{J} 8$ & Not observed \\
\hline & $\mathrm{J} 20$ & Not observed \\
\hline & $\mathrm{J} 35$ & Not observed \\
\hline & Y13 & Not observed \\
\hline & Y17 & Not observed \\
\hline
\end{tabular}

Values are expressed as the number of animals that presented behavioural alterations in comparison with the total number of evaluated animals.
TABLE V

Effect of acute treatment with J1, J8, J20, J35, Y13 and Y17 $(300 \mathrm{mg} / \mathrm{kg})$ or vehicle, observed during $0.25,0.5,1,2,4$, 8 and $24 \mathrm{~h}$ after oral administration, on some behavioural parameters indicative of acute toxicity in mice.

\begin{tabular}{ccc}
\hline $\begin{array}{c}\text { Evaluated } \\
\text { parameters }\end{array}$ & $\begin{array}{c}\text { Dose } \\
\mathbf{( 3 0 0} \mathbf{~ m g / k g , ~ p . o . )}\end{array}$ & Response \\
\hline \multirow{2}{*}{$\begin{array}{c}\text { Straub's } \\
\text { Signal }\end{array}$} & Vehicle & Not observed \\
& J1 & Not observed \\
& J8 & Not observed \\
& J35 & Not observed \\
& Y13 & Not observed \\
& Y17 & Not observed \\
Ptosis & Vehicle & Not observed \\
\hline \multirow{3}{*}{ lacrimation) } & J1 & Not observed \\
& J8 & Not observed \\
& J20 & Not observed \\
& J35 & Not observed \\
& Y13 & Not observed \\
Y17 & Not observed \\
\hline \multirow{3}{*}{ Piloerection } & Vehicle & Not observed \\
& J1 & Not observed \\
& J8 & Not observed \\
& J20 & Not observed \\
& J35 & Not observed \\
& Y13 & Not observed \\
& Y17 & Not observed \\
\hline
\end{tabular}

Values are expressed as the number of animals that presented behavioural alterations in comparison with the total number of evaluated animals.

\section{TABLE VI}

Effect of acute treatment with $\mathrm{J1}, \mathrm{J8}, \mathrm{J20}, \mathrm{J35}, \mathrm{Y} 13$ and Y17 $(300 \mathrm{mg} / \mathrm{kg})$ or vehicle, after oral administration in males and females, on changes in the average of food and water intake evaluated at the end of treatment.

\begin{tabular}{cccc}
\hline $\begin{array}{c}\text { Group } \\
\mathbf{3 0 0} \mathbf{~ m g} / \mathbf{k g}, \mathbf{p . o .})\end{array}$ & $\mathbf{n}$ & Food $(\mathbf{g})$ & Water $(\mathbf{m L})$ \\
\hline Vehicle & 9 & $5.87 \pm 0.86$ & $5.79 \pm 0.28$ \\
$\mathbf{J 1}$ & 12 & $6.04 \pm 0.54$ & $5.98 \pm 0.36$ \\
$\mathbf{J 8}$ & 11 & $6.12 \pm 0.47$ & $6.10 \pm 0.39$ \\
$\mathbf{J 2 0}$ & 10 & $7.45 \pm 1.02$ & $6.96 \pm 0.39$ \\
$\mathbf{J 3 5}$ & 10 & $7.63 \pm 0.97$ & $7.01 \pm 0.53$ \\
Y13 & 11 & $7.90 \pm 1.07$ & $7.67 \pm 1.59$ \\
Y17 & 10 & $6.23 \pm 0.55$ & $6.56 \pm 0.46$ \\
\hline
\end{tabular}

Values represent the variation of mean solid (g/animal/day) and liquid (mL/animal/day) intake of 9-12 animals \pm standard error mean. Two-way ANOVA with repeated measures shows no difference between the groups. 
A

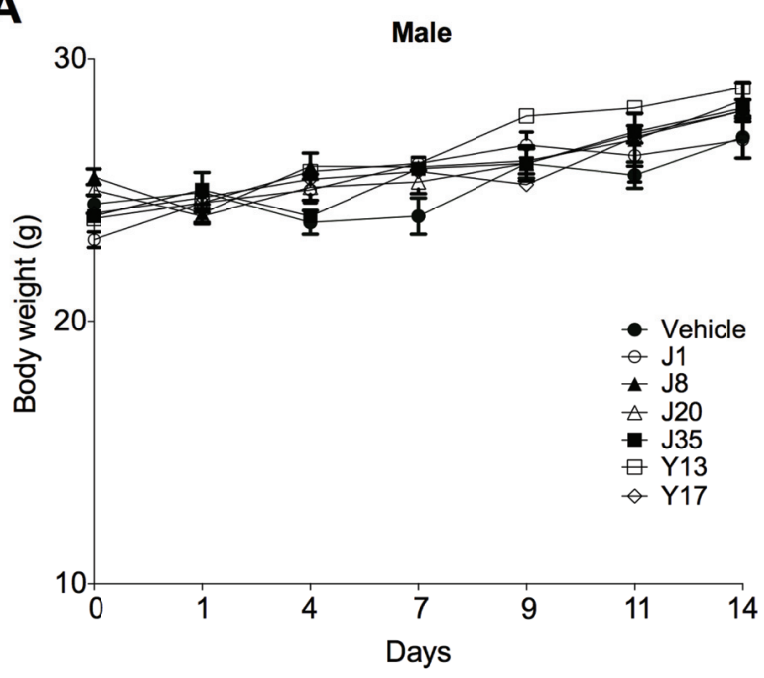

B

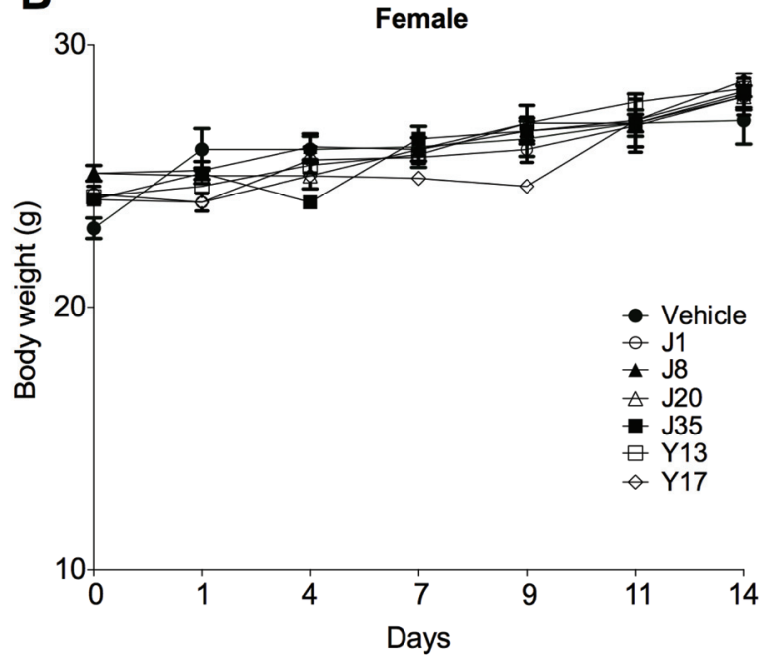

Figure 2 - Effect of acute treatment with J1, J8, J20, J35, Y13 and Y17 (300 mg/kg) or vehicle, administered orally as a single dose, on absolute body weight of (A) male and (B) female mice. Each value represents mean of 9-12 animals and vertical lines represent S.E.M. Two-way ANOVA with repeated measures.

thymus, mesenteric lymph node and encephalon), when compared with the control group (vehicle), all of which were evaluated at the $14^{\text {th }}$ day of study. Furthermore, mice acutely treated orally with J1, J8, J20, J35, Y13 and Y17 (300 mg/kg), did not show significant differences in either relative or absolute weight of heart, lung, kidney, spleen, stomach, salivary gland, adrenal gland, thymus and encephalon when compared with the control group, all of which were evaluated at the $14^{\text {th }}$ day of study (Table VII). Only treatment with J1 resulted in significant increase in the relative weight of the testis (Table VII).

Next, we evaluated the systemic effects of intraperitoneal administration of selected compounds from the J series (J1, J8 and J35). Only three compounds were assayed in this set of experiments because limited amounts of the other compounds were available to complete the assay. In this set of experiments, mice were treated with multiple doses (10 mg/kg, 3 times a week, i.p.), as this will be the probable dosing regimen for future in vivo assays with scrapie-infected mice. Moreover, at this selected dose, the compound concentration will be above the estimated $\mathrm{IC}_{50}$ values (Ferreira et al. 2014). When evaluated for 28 days, none of the tested compounds induced mouse mortality (data not shown) and no significant alterations in body weight were observed in mice treated with $\mathrm{J} 1$, J8 or J35 (10 mg/kg, 3 times a week, i.p., for 28 days) when compared with control mice (Fig. 3). Macroscopic evaluation of the selected organs and glands (heart, lung, liver, kidney, spleen, stomach, adrenal gland, and encephalon) demonstrated no alterations of aspect and color in mice treated with $\mathrm{J} 1(10 \mathrm{mg} / \mathrm{kg}, 3$ times a week, i.p.), evaluated at the $28^{\text {th }}$ day of study, when compared with the control group (vehicle). Similar results were found for $\mathrm{J} 8$ and $\mathrm{J} 35$; however, one mouse treated with $\mathrm{J} 8$ and one with $\mathrm{J} 35(10 \mathrm{mg} / \mathrm{kg}, 3$ times a week, i.p.) showed minor lung bleeding, and one mouse treated with $\mathrm{J} 35$ presented kidney discoloration. In addition, systemic treatment with $\mathrm{J} 1, \mathrm{~J} 8$, or $\mathrm{J} 35$ $(10 \mathrm{mg} / \mathrm{kg}, 3$ times a week, i.p.) for 28 days was not capable of inducing significant alterations in absolute and relative weight of lung, liver, kidney, spleen, stomach, adrenal gland, and encephalon, when compared with the control group. However, 


\section{TABLE VII}

Effect of acute treatment with J1, J8, J20, J35, Y13 and Y17, after oral administration, on relative weight of some organs and glands of male and female mice.

\begin{tabular}{|c|c|c|c|c|c|c|c|}
\hline Structure & Vehicle & $\mathbf{J 1}$ & J8 & J20 & J35 & Y13 & Y17 \\
\hline Spleen & $\begin{array}{c}0.33 \\
(0.27-0.40)\end{array}$ & $\begin{array}{c}0.41 \\
(0.34-0.47)\end{array}$ & $\begin{array}{c}0.33 \\
(0.31-0.36)\end{array}$ & $\begin{array}{c}0.31 \\
(0.27-0.35)\end{array}$ & $\begin{array}{c}0.42 \\
(0.33-0.51)\end{array}$ & $\begin{array}{c}0.27 \\
(0.24-0.34)\end{array}$ & $\begin{array}{c}0.27 \\
(0.23-0.31)\end{array}$ \\
\hline Kidney & $\begin{array}{c}0.75 \\
(0.72-0.78)\end{array}$ & $\begin{array}{c}0.59 \\
(0.55-0.62)\end{array}$ & $\begin{array}{c}0.76 \\
(0.69-0.83)\end{array}$ & $\begin{array}{c}0.70 \\
(0.64-0.75)\end{array}$ & $\begin{array}{c}0.75 \\
(0.70-0.80)\end{array}$ & $\begin{array}{c}0.67 \\
(0.52-0.82)\end{array}$ & $\begin{array}{c}0.76 \\
(0.60-0.91)\end{array}$ \\
\hline Heart & $\begin{array}{c}0.50 \\
(0.46-0.54)\end{array}$ & $\begin{array}{c}0.46 \\
(0.42-0.49)\end{array}$ & $\begin{array}{c}0.48 \\
(0.44-0.52)\end{array}$ & $\begin{array}{c}0.43 \\
(0.40-0.46)\end{array}$ & $\begin{array}{c}0.51 \\
(0.47-0.54)\end{array}$ & $\begin{array}{c}0.53 \\
(0.41-0.64)\end{array}$ & $\begin{array}{c}0.46 \\
(0.36-0.56)\end{array}$ \\
\hline Lung & $\begin{array}{c}0.87 \\
(0.66-1.07) \\
\end{array}$ & $\begin{array}{c}0.79 \\
(0.71-0.87) \\
\end{array}$ & $\begin{array}{c}0.75 \\
(0.64-0.86) \\
\end{array}$ & $\begin{array}{c}0.65 \\
(0.53-0.76) \\
\end{array}$ & $\begin{array}{c}0.80 \\
(0.65-0.94) \\
\end{array}$ & $\begin{array}{c}0.69 \\
(0.60-0.70) \\
\end{array}$ & $\begin{array}{c}0.63 \\
(0.59-0.68) \\
\end{array}$ \\
\hline Liver & $\begin{array}{c}5.40 \\
(4.90-5.90)\end{array}$ & $\begin{array}{c}4.30 \\
(4.00-4.60)\end{array}$ & $\begin{array}{c}5.10 \\
(4.80-5.30)\end{array}$ & $\begin{array}{c}4.80 \\
(4.50-5.10)\end{array}$ & $\begin{array}{c}4.90 \\
(4.40-5.20)\end{array}$ & $\begin{array}{c}4.70 \\
(4.20-5.20)\end{array}$ & $\begin{array}{c}4.90 \\
(4.60-5.20)\end{array}$ \\
\hline $\begin{array}{l}\text { Mesenteric } \\
\text { lymph node }\end{array}$ & $\begin{array}{c}0.17 \\
(0.10-0.24)\end{array}$ & $\begin{array}{c}0.09 \\
(0.04-0.15)\end{array}$ & $\begin{array}{c}0.15 \\
(0.10-0.20)\end{array}$ & $\begin{array}{c}0.11 \\
(0.07-0.15)\end{array}$ & $\begin{array}{c}0.08 \\
(0.04-0.13)\end{array}$ & $\begin{array}{c}0.05 \\
(0.009-0.09)\end{array}$ & $\begin{array}{c}0.12 \\
(0.01-0.27)\end{array}$ \\
\hline Adrenal gland & $\begin{array}{c}0.02 \\
(0.01-0.02) \\
\end{array}$ & $\begin{array}{c}0.02 \\
(0.01-0.02) \\
\end{array}$ & $\begin{array}{c}0.02 \\
(0.01-0.02) \\
\end{array}$ & $\begin{array}{c}0.01 \\
(0.008-0.02) \\
\end{array}$ & $\begin{array}{c}0.01 \\
(0.009-0.02) \\
\end{array}$ & $\begin{array}{c}0.01 \\
(0.01-0.016) \\
\end{array}$ & $\begin{array}{c}0.02 \\
(0.01-0.04) \\
\end{array}$ \\
\hline Thymus & $\begin{array}{c}0.18 \\
(0.13-0.23) \\
\end{array}$ & $\begin{array}{c}0.20 \\
(0.17-0.23) \\
\end{array}$ & $\begin{array}{c}0.20 \\
(0.16-0.23) \\
\end{array}$ & $\begin{array}{c}0.17 \\
(0.11-0.24) \\
\end{array}$ & $\begin{array}{c}0.15 \\
(0.10-0.20) \\
\end{array}$ & $\begin{array}{c}0.13 \\
(0.07-0.17) \\
\end{array}$ & $\begin{array}{c}0.21 \\
(0.15-0.27) \\
\end{array}$ \\
\hline Stomach & $\begin{array}{c}0.72 \\
(0.64-0.81)\end{array}$ & $\begin{array}{c}0.86 \\
(0.79-0.93)\end{array}$ & $\begin{array}{c}0.86 \\
(0.69-0.91)\end{array}$ & $\begin{array}{c}0.84 \\
(0.72-0.96)\end{array}$ & $\begin{array}{c}0.68 \\
(0.47-0.89)\end{array}$ & $\begin{array}{c}0.72 \\
(0.65-0.78)\end{array}$ & $\begin{array}{c}0.74 \\
(0.49-0.99)\end{array}$ \\
\hline Encephalon & $\begin{array}{c}1.50 \\
(1.40-1.60) \\
\end{array}$ & $\begin{array}{c}1.60 \\
(1.50-1.70) \\
\end{array}$ & $\begin{array}{c}1.50 \\
(1.40-1.60) \\
\end{array}$ & $\begin{array}{c}1.30 \\
(1.20-1.40) \\
\end{array}$ & $\begin{array}{c}1.60 \\
(1.50-1.70) \\
\end{array}$ & $\begin{array}{c}1.60 \\
(1.50-1.70) \\
\end{array}$ & $\begin{array}{c}1.80 \\
(0.60-2.90) \\
\end{array}$ \\
\hline Testis & $\begin{array}{c}0.32 \\
(0.30-0.33) \\
\end{array}$ & $\begin{array}{c}1.00^{*} \\
(0.90-1.20) \\
\end{array}$ & $\begin{array}{c}0.27 \\
(0.21-0.33) \\
\end{array}$ & $\begin{array}{c}0.26 \\
(0.20-0.32) \\
\end{array}$ & $\begin{array}{c}0.30 \\
(0.26-0.34) \\
\end{array}$ & $\begin{array}{c}0.28 \\
(0.23-0.33) \\
\end{array}$ & $\begin{array}{c}0.28 \\
(0.19-0.37) \\
\end{array}$ \\
\hline Salivary gland & $\begin{array}{c}0.30 \\
(0.25-0.36) \\
\end{array}$ & $\begin{array}{c}0.23 \\
(0.14-0.32)\end{array}$ & $\begin{array}{c}0.31 \\
(0.27-0.35)\end{array}$ & $\begin{array}{c}0.28 \\
(0.24-0.33)\end{array}$ & $\begin{array}{c}0.46 \\
(0.33-0.95)\end{array}$ & $\begin{array}{c}0.33 \\
(0.31-0.35)\end{array}$ & $\begin{array}{c}0.29 \\
(0.20-0.37) \\
\end{array}$ \\
\hline
\end{tabular}

Values represent the mean of organs weight of 9-12 animals with $95 \%$ of confidence interval.

Values were obtained from the relation (percentage) of organ weight to body mass of animals (using the following formula: organ weight/body weight $\mathrm{x}$ 100). Two-way ANOVA except for testis where one-way ANOVA was used. $* \mathrm{p} \leq 0.05$ when compared with the vehicle group.

TABLE VIII

Effect of repeated i.p. administration of $\mathrm{J1}$, $\mathrm{J8}$ and $\mathrm{J35}$ on relative weight of some organs of mice.

\begin{tabular}{|c|c|c|c|c|}
\hline Structure & Vehicle & J1 & J8 & J35 \\
\hline Spleen & $\begin{array}{c}0.53 \\
(0.41-0.65) \\
\end{array}$ & $\begin{array}{c}0.49 \\
(0.44-0.54) \\
\end{array}$ & $\begin{array}{c}0.51 \\
(0.47-0.55) \\
\end{array}$ & $\begin{array}{c}0.53 \\
(0.45-0.60) \\
\end{array}$ \\
\hline Kidney & $\begin{array}{c}0.53 \\
(0.41-0.56)\end{array}$ & $\begin{array}{c}0.49 \\
(0.44-0.54)\end{array}$ & $\begin{array}{c}0.56 \\
(0.47-0.55)\end{array}$ & $\begin{array}{c}0.53 \\
(0.45-0.60)\end{array}$ \\
\hline Heart & $\begin{array}{c}0.47 \\
(0.41-0.53)\end{array}$ & $\begin{array}{c}0.52 \\
(0.44-0.60)\end{array}$ & $\begin{array}{c}0.49 \\
(0.41-0.58)\end{array}$ & $\begin{array}{c}0.61 * \\
(0.52-0.71)\end{array}$ \\
\hline Lung & $\begin{array}{c}0.58 \\
(0.46-0.70)\end{array}$ & $\begin{array}{c}0.58 \\
(0.57-0.59)\end{array}$ & $\begin{array}{c}0.58 \\
(0.47-0.68)\end{array}$ & $\begin{array}{c}0.57 \\
(0.53-0.61)\end{array}$ \\
\hline Liver & $\begin{array}{c}4.76 \\
(4.15-5.37) \\
\end{array}$ & $\begin{array}{c}4.91 \\
(4.25-5.57)\end{array}$ & $\begin{array}{c}4.62 \\
(4.00-5.24)\end{array}$ & $\begin{array}{c}4.73 \\
(4.38-5.09)\end{array}$ \\
\hline Adrenal gland & $\begin{array}{c}0.03 \\
(0.02-0.04) \\
\end{array}$ & $\begin{array}{c}0.03 \\
(0.02-0.04) \\
\end{array}$ & $\begin{array}{c}0.04 \\
(0.03-0.05) \\
\end{array}$ & $\begin{array}{c}0.04 \\
(0.03-0.05)\end{array}$ \\
\hline Stomach & $\begin{array}{c}0.85 \\
(0.75-0.95) \\
\end{array}$ & $\begin{array}{c}0.93 \\
(0.79-1.07) \\
\end{array}$ & $\begin{array}{c}0.99 \\
(0.89-1.09) \\
\end{array}$ & $\begin{array}{c}0.92 \\
(0.87-0.97) \\
\end{array}$ \\
\hline Encephalon & $\begin{array}{c}1.21 \\
(1.03-1.38)\end{array}$ & $\begin{array}{c}1.34 \\
(1.24-1.44)\end{array}$ & $\begin{array}{c}1.29 \\
(1.23-1.35)\end{array}$ & $\begin{array}{c}1.28 \\
(1.14-1.42)\end{array}$ \\
\hline
\end{tabular}

Values represent the mean of organs weight of 5-6 animals with $95 \%$ of confidence interval.

Values were obtained from the relation (percentage) of organ weight to body mass of animals (using the following formula: organ weight/body weight $\mathrm{x} 100){ }^{*} \mathrm{p} \leq 0.05$ when compared with the vehicle group. 


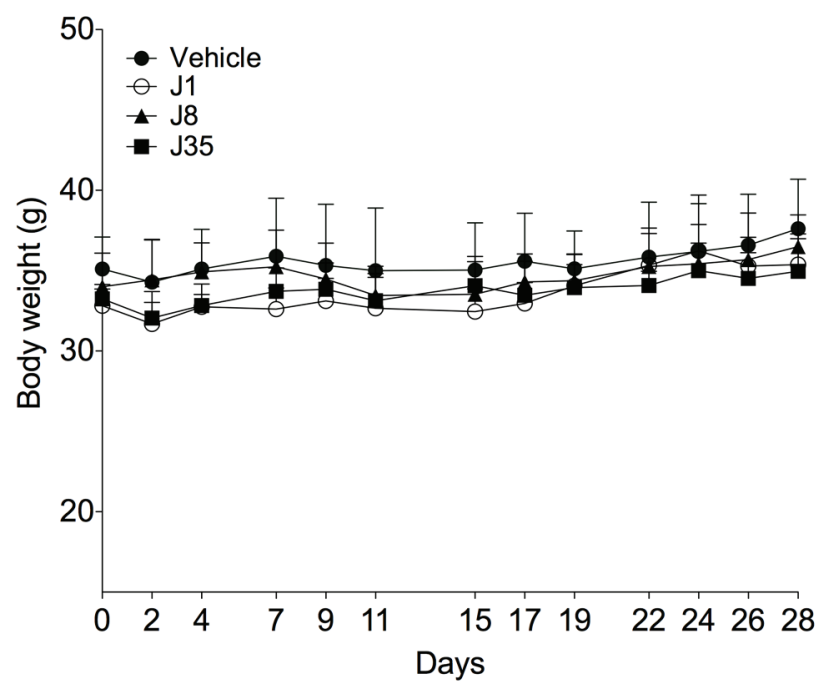

Figure 3 - Effect of repeated treatment with J1, J8, J35 (10 mg/kg) or vehicle, administered intraperitoneally for 28 days ( 3 times a week), on absolute body weight of female mice. Each value represents mean of 6 animals and vertical lines represent S.E.M. Two-way ANOVA with repeated measures shows no difference between the groups.

J35 caused significant increase in the relative weight of heart of mice following i.p. treatment (10 mg/kg, 3 times a week, during 4 weeks, i.p.) (Table VIII).

In conclusion, analyses of results demonstrated that acute oral administration of J1, J8, J20, J35, Y13 and Y17, and intraperitoneal repeated doses of J1, J8 and J35 showed good tolerability and had no acute toxic effects in mice, when evaluated on several behavioral parameters. The six compounds showed low acute toxicity and did not cause alterations in body mass or food and water intake in mice. In addition, the acute oral administration of these compounds did not lead to important macroscopic alteration concerning the aspect, color and size of organs and/or glands, such as heart, lung, liver, kidney, spleen, stomach, ovary and uterine tubes, salivary gland, adrenal gland, thymus, mesenteric lymph node and encephalon, when compared with organs of control mice. J1, J8 and $\mathrm{J} 35$ also indicated being safe when administered systemically, with only one mouse treated with J8 and one with J35 showing minor lung bleeding, kidney discoloration and increased relative weight of the heart when compared with the control group.

\section{DISCUSSION}

Chalcones and oxadiazoles are chemical classes of compounds with several biological activities, but to date only our previous report revealed their putative anti-scrapie activity (Ferreira et al. 2014). Particularly, 1,3,4-oxadiazoles with different substituents have been assayed for antiinflammatory, anti-tumor, analgesic, anti-viral and antimicrobial activities (Omar et al. 1996, Sun et al. 2013), being considered privileged structures in medicinal chemistry (Rane et al. 2013). Acute toxicity studies of substituted 1,3,4-oxadiazoles that have anti-inflammatory and analgesic activities showed $\mathrm{LD}_{50}$ values of $\sim 1000 \mathrm{mg} / \mathrm{kg}$ after i.p. administration to mice (Omar et al. 1996). As we did not reach such dose in our study, we can only suppose that Y13 and Y17 will also have high $\mathrm{LD}_{50}$ values. However, we are dealing with different oxadiazole derivatives, what can completely alter the PK profile. Recently, anti-bacterial, anti-fungal 
and anti-tubercular activities were described for 4-nitropyrrole-based 1,3,4-oxadiazoles. Their $\mathrm{IC}_{50}$ values for cytotoxicity in mammalian VERO cells ranged from 100-700 $\mu \mathrm{M}$ (Rane et al. 2013), much higher than the minimum inhibitory concentrations (MIC). Our previous study also showed that Y13 and Y17 are non-toxic to cultured mammalian cells at and above the effective anti-scrapie concentration (Ferreira et al. 2014).

Besides having several known pharmacological activities, the synthesis of chalcones is rapid, low cost and normally with high yields, which renders this class of compounds promising for drug development. Other 3,4,5-trimethoxychalcone analogues presented potent activity against $H$. pylori (Lai et al. 2010) and inhibited both nitric oxide production and tumor cell proliferation (Rao et al. 2009). The 3,4,5-trimethoxyphenyl ring is increasingly associated with antitumor activity of several chalcone derivatives. Although differing in the methoxy position, the 2,4,5-trimethoxychalcones investigated here ( $\mathrm{J} 8$, $\mathrm{J} 20$ and J35) also had anti-proliferative activity against K652 leukemia cells (Costa et al. 2014). However, J8 and J20 reduced cell viability in only 30-35 \%, and $\mathrm{J} 35$ to $50 \%$ at $100 \mu \mathrm{M}$. J1 had no significant activity (Costa el al. 2014). Cytotoxicity against non-tumoral cell lines was investigated by us, and what we found is that the chalcones were not toxic to N2a cells in concentrations of up to 25 $\mu \mathrm{M}$ (Ferreira et al. 2014). Nonetheless, it remains to be confirmed whether these compounds are safe to non-tumoral cells at higher concentrations.

Regarding the ability to cross the BBB, there is lack of in vivo PK studies with the chalcones and oxadiazoles investigated here. A trimethoxychalcone derivative was detected in implanted glioblastoma tumors and in the brain of i.p. treated mice, showing that at least this specific chalcone crosses the BBB (Boumendjel et al. 2009). Previously, we used a computational approach to predict some pharmacokinetic parameters that helped us select the most promising compounds to assay in vivo. Our in silico analysis indicated that the fraction of J1, J35, Y13 and Y17 that reaches circulation after oral administration is theoretically expected to be higher than $70 \%$, while for $\mathrm{J} 8$ and $\mathrm{J} 20$ it stands between 30 and $70 \%$. These compounds were also classified as sufficiently CNS-permeable to be active in the CNS. These ADMET predictions do not substitute in vivo evaluation, but give us preliminary information on the potential drugability of these compounds (Cordeiro and Ferreira 2015).

All compounds were predicted to have low solubility in water (Table I), what renders them prone to cross the BBB. However, we still have not evaluated (in vitro or in silico) binding to plasma proteins, a feature that compromises permeation to biological membranes, even for lipophilic compounds. Prediction of toxicity indicated that all compounds from the $\mathrm{J}$ series are less toxic than compounds from the Y series (Table I). We were not able to calculate $\mathrm{LD}_{50}$ values for the compounds, as oral and i.p. administration of both Ys and Js as single or multiple doses did not cause death of the treated mice. Consequently, although the in silico toxicity prediction supported the in vivo results for the chalcones, we could not correlate the $\mathrm{LD}_{50}$ prediction for compounds of the Y series (Table I) to the obtained in vivo results.

Sub-acute and chronic toxicity studies are needed to provide data on genotoxicity, mutagenicity, and on long-term effects in organs and glands and overall animal behavior. However, the acute toxicity results presented here show that at least the compounds are safe regarding oral and i.p. administration at the investigated doses. Previous data showing the pharmaceutical importance of the 1,3,4-oxadiazole and trimethoxychalcone scaffolds (Sun et al. 2013, Rane et al. 2013, Omar et al. 1996, Costa el al. 2014, Ferreira et al. 2014), together with our in vivo acute toxicity results strongly indicate that J1, J8, J20, J35, Y13 and Y17 are interesting compounds for further investigation as anti-scrapie drugs or for other activities. Further structural modifications might also generate novel compounds with low toxicity and high potency. 


\section{ACKNOWLEDGMENTS}

We thank Dr. Maria Letícia de Castro Barbosa and Dr. Julia R. Clarke from the Faculty of Pharmacy, UFRJ for critical reading and revision of the manuscript and Wesley J. A. da Conceição for helping to elaborate Fig. 1. We also thank Dr. Patricia N. Fernandes for excellent technical support. This work was supported by grants from Conselho Nacional de Desenvolvimento Científico e Tecnológico (CNPq); from the Instituto Nacional de Ciência e Tecnologia de Biologia Estrutural e Bioimagem (INBEB); Fundação de Amparo à Pesquisa do Estado do Rio de Janeiro (FAPERJ); Coordenação de Aperfeiçoamento de Pessoal de Nível Superior (CAPES)- PROCAD/ Casadinho: Fortalecimento e Consolidação da Área de Farmacologia e Toxicologia Pré-Clínica do Programa de Pós-Graduação em Ciências Farmacêuticas da Universidade Federal do Rio de Janeiro (UFRJ/UFSC).

\section{RESUMO}

Uma forma alterada da proteína prion celular, a $\operatorname{PrP}^{\mathrm{Sc}}$ ou $\mathrm{PrP}^{\mathrm{Res}}$, está envolvida na ocorrência das encefalopatias espongiformes transmissíveis. Nós sintetizamos e caracterizamos previamente compostos aromáticos que inibem o acúmulo da proteína prion resistente a proteases $\left(\mathrm{PrP}^{\mathrm{Res}}\right)$ em células infectadas com prion scrapie. Estes compostos pertencem a diferentes classes químicas, incluindo acilhidrazonas, chalconas e oxadiazóis. Alguns dos compostos ativos não apresentaram toxicidade para células de neuroblastoma em cultura e parecem apresentar propriedades de fármacos, uma vez que todos obedecem aos 5 quesitos da regra de Lipinski e apresentam perfil farmacocinético desejável, como predito in silico. Antes de avaliar a eficácia in vivo dos compostos aromáticos em camundongos infectados com prion scrapie, é necessário estimar sua segurança em camundongos saudáveis. Neste trabalho nós utilizamos camundongos Suíços para avaliar o perfil de toxicidade aguda dos seis compostos mais promissores, as 2,4,5-trimetoxichalconas (J1, J8, J20 e J35) e os 1,3,4-oxadiazóis (Y13 e Y17). Administração oral em dose única (300 mg/kg) de J1, J8, J20, J35, Y13 e Y17 ou administração repetida via intraperitoneal (10 $\mathrm{mg} / \mathrm{kg}, 3$ vezes por semana, por 4 semanas) de J1, J8 e J35, não geraram toxicidade nos camundongos. Nós acreditamos fortemente que as trimetoxichalconas e os oxadiazóis investigados são compostos interessantes para serem futuramente avaliados in vivo contra as doenças causadas por prions.

Palavras-chave: prion, toxicidade aguda, composto orgânico, segurança de fármacos, scrapie, farmacocinética.

\section{REFERENCES}

ACD/Labs Percepta Platform. 2014. Version 12.01, Advanced Chemistry Development, Inc. (ACD/Labs), Toronto, On, Canada. www.acdlabs.com.

ANVISA. 2010. Guia para a condução de estudos não clínicos de segurança necessários ao desenvolvimento de medicamentos. Brasília, Brasil, p. 6-8.

BorchHardt DM, Mascarello A, Chiaradia LD, NunES RJ, Oliva G, Yunes RA AND ANDRICOPUlo AD. 2010. Biochemical evaluation of a series of synthetic chalcone and hydrazide derivatives as novel inhibitors of cruzain from Trypanosoma cruzi. J Braz Chem Soc 21: 142-150.

Boumendjel A, Mcleer-Florin A, Champelovier P, Allegro D, Muhammad D, Souard F, Derouazi M, Peyrot V, Toussaint B And Boutonnat J. 2009. A novel chalcone derivative which acts as a microtubule depolymerising agent and an inhibitor of P-gp and BCRP in in-vitro and in-vivo glioblastoma models. BMC Cancer 9: 242.

BRANDÃO DC. 2004. Resolução-RE no 90, 16 de março. In: Registro de Fitoterápicos, PHC Pharma Consulting.

CASHMAN NR AND CAUGHEY B. 2004. Prion diseases-close to effective therapy? Nat Rev Drug Discov 3: 874-884.

COBEA - COLÉGIO BRASILEIRO DE EXPERIMENTAÇÃo ANIMAL. 1991. Os princípios éticos da experimentação animal. São Paulo, Brasil.

COLlinge J ET AL. 2009. Safety and efficacy of quinacrine in human prion disease (PRION-1 study): a patientpreference trial. Lancet Neurol 8: 334-344.

CORDEIRO Y AND FERREIRA NC. 2015. New approaches for the selection and evaluation of anti-prion organic compounds. Mini Rev Med Chem 15: 84-92.

Costa A ET AL. 2014. Apoptotic effect of synthetic 2',4',5'-trimethoxychalcones in human K562 and Jurkat leukemia cells. Med Chem Res 23: 4301-4319.

DoH-URA K, IWAKI T AND CAUGHEY B. 2000. Lysosomotropic agents and cysteine protease inhibitors inhibit scrapieassociated prion protein accumulation. J Virol 74: 48944897. 
FERREIRA NC ET AL. 2014. Anti-prion activity of a panel of aromatic chemical compounds: in vitro and in silico approaches. PLoS One 9(1): e84531.

Forloni G, ARTUSO V, ROITER I, MORBIN M AND TAGLIAVINI F. 2013. Therapy in prion diseases. Curr Top Med Chem 13: 2465-2476.

FURUKAWA H, TAKAHASHI M, NAKAJIMA M AND YAMADA T. 2002. Prospects of the therapeutic approaches to Creutzfeldt-Jacob disease: a clinical trial of antimalarial quinacrine. Nihon Rinsho 60: 1649-1657.

GHAEMmaghami S, MAY BC, RENSLO AR AND PRUSINER SB. 2010. Discovery of 2-aminothiazoles as potent antiprion compounds. J Virol 84: 3408-3412.

HAÏK S ET AL. 2014. Doxycycline in Creutzfeldt-Jakob disease: a phase 2, randomised, double-blind, placebo-controlled trial. Lancet Neurol 13: 150-158.

Kocisko DA, Baron GS, Rubenstein R, Chen J, Kuizon S AND CAUGHEY B. 2003. New inhibitors of scrapieassociated prion protein formation in a library of 2000 drugs and natural products. J Virol 77: 10288-10294.

Kocisko DA AND CAUGHEY B. 2006. Searching for antiprion compounds: cell-based high-throughput in vitro assays and animal testing strategies. Methods Enzymol 412: 223-234.

Korth C, May BC, Cohen FE ANd Prusiner SB. 2001. Acridine and phenothiazine derivatives as pharmacotherapeutics for prion disease. Proc Natl Acad Sci USA 98: 9836-9841.

Koster T, Singh K, Zimmermann M AND GruYs E. 2003. Emerging therapeutic agents for transmissible spongiform encephalopathies: a review. J Vet Pharmacol Ther 26: 315326.

LAI CH, RAO YK, FANG SH, Sing YT AND TZENG YM. 2010. Identification of 3',4',5'-trimethoxychalcone analogues as potent inhibitors of Helicobacter pylori-induced inflammation in human gastric epithelial cells. Bioorg Med Chem Lett 20: 5462-5465.

Li Z, Rao S, Gever JR, Widjaja K, Prusiner SB And SILBER BM. 2013. Optimization of Arylamides as Novel, Potent and Brain-penetrant Antiprion Lead Compounds. ACs Med Chem Lett 4: 647-650.

Macedo B, Kaschula CH, Hunter R, Chaves JA, Van Der Merwe JD, Silva JL, Egan TJ AND Cordeiro Y. 2010. Synthesis and anti-prion activity evaluation of aminoquinoline analogues. Eur J Med Chem 45: 54685473.
MartíneZ-Lage JF, RÁBAno A, Bermejo J, Martínez PÉreZ M, Guerrero MC, Contreras MA and Lunar A. 2005. Creutzfeldt-Jakob disease acquired via a dural graft: failure of therapy with quinacrine and chlorpromazine. Surg Neurol 64: 542-54.

NunES RJ ETAL. 2012. Compostos acil-hidrazonas e oxadiazóis, composições farmacêuticas compreendendo os mesmos e seus usos. Brazilian patent: PCT/BR2012/000480.

OECD. 2001. Guideline for the testing of chemicals, Section 4: Health Effects. Acute oral toxicity - Acute toxic class method, Test no 423, $14 \mathrm{p}$.

OMAR F, MAHFOUZ N AND RAHMAN M. 1996. Design, synthesis and antiinflammatory activity of some 1,3,4-oxadiazole derivatives. Eur J Med Chem 31: 819-825.

Otто M ET AL. 2004. Efficacy of flupirtine on cognitive function in patients with CJD: A double-blind study. Neurology 62: 714-718.

PRUSINER SB. 1998. Prions. Proc Natl Acad Sci USA 95: 13363-13383.

RAINOV NG, TSUBOI Y, KROLAK-SALMON P, VighETTO A AND DOH-URA K. 2007. Experimental treatments for human transmissible spongiform encephalopathies: is there a role for pentosan polysulfate? Expert Opin Biol Ther 7: 713726.

RANE RA, BANGALORE P, Borhade SD AND KHANDARE PK. 2013. Synthesis and evaluation of novel 4-nitropyrrolebased 1,3,4-oxadiazole derivatives as antimicrobial and anti-tubercular agents. Eur J Med Chem 70: 49-58.

RAO YK, FANG SH AND TZENG YM. 2009. Synthesis and biological evaluation of 3',4',5'-trimethoxychalcone analogues as inhibitors of nitric oxide production and tumor cell proliferation. Bioorg Med Chem 17: 79097914.

SilBer BM ET AL. 2013. Pharmacokinetics and metabolism of 2-aminothiazoles with antiprion activity in mice. Pharm Res 30: 932-950.

SIM VL. 2012. Prion disease: chemotherapeutic strategies. Infect Disord Drug Targets 12: 144-160.

SUN J, MAKAWANA JA AND ZHU HL. 2013. 1,3,4-oxadiazole derivatives as potential biological agents. Mini Rev Med Chem 13: 1725-1743.

TSUBOI Y, DOH-URA K AND YAMADA T. 2009. Continuous intraventricular infusion of pentosan polysulfate: clinical trial against prion diseases. Neuropathology 29: 632-636. 